\title{
Meat slurry and my particular brand of optimism
}

Diana M. Cejas, MD, MPH

Neurolog ${ }^{\circledR}$ 2018;90:479-480. doi:10.1212/WNL.0000000000005078

The commercials were the worst. You never notice how many there are until you're made NPO. I stared up at the television, stroked out and glassy-eyed, and marveled at it all. The way milk splashes into a cereal bowl and scatters colorful oat rings. Golden, gleaming rotisserie chickens paired with mounds of creamy mashed potatoes-each topped by pools of velvety gravy. Cheesy pizzas laden with spicy pepperoni, juicy burgers with crisp bacon and ripe tomatoes, ice creams and milkshakes, and chocolate everything called to me through the screen.

The first thing that I got to eat after my stroke was a saltine. Unsalted. "It's safer that way," the neuro ICU resident said. I aspirated after each sip of water. I drooled, I coughed, I rasped my way through every conversation. I got a saltine. I bit it with the side of my mouth that still worked and the white flour and iodized salt was like manna to me. Nearly anything tastes like love and sunshine on a 6-day-empty belly. I finished 2 crackers and was cut off. I wiped the drool from my drooping mouth, closed my eyes, and dreamed of congri (a Cuban dish made with black beans and rice).

Eating loses its shine quickly when all you're allowed to have is dry saltines and stale graham crackers. It becomes a chore when chewing is exhausting and painful. That was one of the hardest things for me to deal with, since I loved food so much. My baby stories are about peaches (my favorite) and hotdogs (my first word) and pork chops (long story). I navigate cities by finding markets and restaurants. I lived in New Orleans, for goodness' sake. But I had cancer and then a stroke, and I was left with a deviated, macerated tongue and nothing but 2 flavorless saltines in my one functional hand. I stared up at the television, surgical wound itching and machines wailing around me, and lamented all that I had lost.

"We're going to advance your diet," my speech therapist said after I'd failed the first and then passed the second swallow study. As my body got a little better, I gained different foods back. Cups of sticky, metallic-tasting puddings were followed by powdered eggs and hospital macaroni and cheese. We toasted my ability to climb 5 stairs with nectar-thickened fruit punch. I slowly, carefully ate half of a plate of overcooked noodles and chunky marinara sauce after I regained the ability to raise my left thumb. It wasn't enough. I'd gone from an active, athletic, independent young woman to an emaciated, defeated, discouraged girl in less than 6 months. I wanted my life back. I wanted gumbo back.

"It'll come," my occupational therapist said after I'd knocked over another cup. And after I'd dropped another therapy ball. And after I'd broken another glass full of thickened tea. "You can't get angry at yourself about these things. Your hand is like a baby again. Parents don't get mad at their babies for breaking things." I looked from her to my weakened hand, thought of every time I'd seen a parent fuss at their baby for doing just that, and scowled.

One day, 2 bites into my artificially flavored apple cinnamon oatmeal, my speech therapist excused herself to check another stroke patient's breakfast. I asked what they were having and she pulled a face. "Well. It's beef broth and thickener. Sometimes we put a little pureed meat in it. Then you mix it all up and make a slurry out of it." I must have looked horrified. "It's good," she said unconvincingly.

Weeks of therapy went by, then months. My walking improved, my speech got clearer, my scar started to heal. I ate doberge (a multilayered cake that originated in New Orleans) cakes and snowballs (a New Orleans dessert that is made of shaved ice and flavored syrup) and red beans and rice. I only coughed a little. I only dropped things when I was tired. But every single time I knocked

\author{
Correspondence \\ Dr. Cejas \\ diana.cejas@cidd.unc.edu
}


something down or drooled in public, or scratched my itchy scar, I thought of bad things first. There's a neurologic ICU that my mind will always go back to when things aren't going right. But ultimately, even when I was at my lowest, my mind would wander back to that meat slurry. I'd think of that other stroke patient. How they might have coveted my boxed potatoes and softened rolls. I think of that first saltine. I picture the smile that my occupational therapist gave me when she ran into me at a seafood restaurant 6 months after the stroke. I wonder what I looked like to her: a crawfish in each hand, a bowl emptied of gumbo before me, a determined look on my face.
I broke another plate yesterday. And, as always, I looked at my impaired hand and started to curse it again and get angry at myself and cry. Then, as always, I swept up the pieces, took 2 deep breaths, and thought of meat slurry.

Things could always be worse.

\section{Acknowledgment}

The author thanks her family, friends, and colleagues for their support and comments on this piece. 


\title{
Neurology
}

\author{
Meat slurry and my particular brand of optimism \\ Diana M. Cejas \\ Neurology 2018;90;479-480 \\ DOI $10.1212 / \mathrm{WNL} .0000000000005078$
}

This information is current as of March 5, 2018

\begin{tabular}{|c|c|}
\hline $\begin{array}{l}\text { Updated Information \& } \\
\text { Services }\end{array}$ & $\begin{array}{l}\text { including high resolution figures, can be found at: } \\
\text { http://n.neurology.org/content/90/10/479.full }\end{array}$ \\
\hline Subspecialty Collections & $\begin{array}{l}\text { This article, along with others on similar topics, appears in the } \\
\text { following collection(s): } \\
\text { All Cerebrovascular disease/Stroke } \\
\text { http://n.neurology.org/cgi/collection/all_cerebrovascular_disease_strok } \\
\text { e } \\
\text { All Rehabilitation } \\
\text { http://n.neurology.org/cgi/collection/all_rehabilitation } \\
\text { Stroke in young adults } \\
\text { http://n.neurology.org/cgi/collection/stroke_in_young_adults }\end{array}$ \\
\hline Permissions \& Licensing & $\begin{array}{l}\text { Information about reproducing this article in parts (figures,tables) or in } \\
\text { its entirety can be found online at: } \\
\text { http://www.neurology.org/about/about_the_journal\#permissions }\end{array}$ \\
\hline Reprints & $\begin{array}{l}\text { Information about ordering reprints can be found online: } \\
\text { http://n.neurology.org/subscribers/advertise }\end{array}$ \\
\hline
\end{tabular}

Neurology ${ }^{\circledR}$ is the official journal of the American Academy of Neurology. Published continuously since 1951, it is now a weekly with 48 issues per year. Copyright @ 2018 American Academy of Neurology. All rights reserved. Print ISSN: 0028-3878. Online ISSN: 1526-632X.

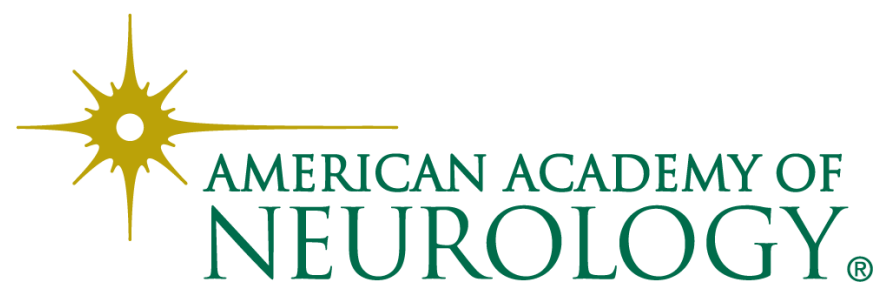

